\title{
Short Note \\ Records of Hippa strigillata (Stimpson, 1860) (Crustacea: Decapoda: Hippidae) in the SE Gulf of California, Mexico
}

\author{
Daniela Ríos-Elósegui and Michel E. Hendrickx*
}

(DRE) Posgrado en Ciencias del Mar y Limnología, Unidad Académica Mazatlán, Instituto de Ciencias del Mar y Limnología, Universidad Nacional Autónoma de México, P.O. Box 811, Mazatlán, Sinaloa 82000, Mexico. E-mail: darielos@hotmail.com

(DRE, MEH) Laboratorio de Invertebrados Bentónicos, Unidad Académica Mazatlán, Instituto de Ciencias del Mar y Limnología, Universidad Nacional Autónoma de México, P.O. Box 811, Mazatlán, Sinaloa 82000, Mexico. E-mail: michel@ola.icmyl.unam.mx; *Corresponding author

\begin{abstract}
This paper presents details regarding the collections and records of H. strigillata in the Bay of Mazatlán, SE Gulf of California, Mexico. Samples of $H$. strigillata were obtained in this bay and suroundings area during different periods and deposited in the collection of UNAM, Mazatlán. Morphometric data, distribution, biological and ecological data were furnished.
\end{abstract}

Key words: Distribution, Gulf of California, Hippa, mole crab

Because they represent a very dynamic environment, often with high energy wave action, sandy beaches are considered low diversity habitats for macro and mega fauna (Tait, 1972). This is particularly true along the west coast of Mexico (Dexter, 1976; Hendrickx, 1996). The intertidal habitat is mostly dominated by species of bivalve mollusks and small (Amphipoda, Isopoda) to medium size (Anomura) crustaceans. Among the Anomura, mole crabs (superfamily Hippoidea) are well adapted to the surf zone and are occasionally very abundant, particularly in the case of the genera Emerita Scopili, 1777 and Hippa Fabricius, 1787 (Barnes and Wenner, 1968; Brusca 1980; Jaramillo et al., 2000a, 2000b; Ríos-Elósegui, 2013).

The superfamily Hippoidea contains three families: Albuneidae, Blepharipodidae, and Hippidae. The Hippidae consists of three genera: Emerita, with 10 species, Mastigochirus Miers, 1878, with two species, and Hippa, with 15 species (Boyko and McLaughlin, 2010). Two species of Hippa occur in the eastern Pacific: Hippa marmorata (Hombron \& Jacquinot, 1846) (a senior synonym of Remipes pacificus Dana, 1852) (Boyko, 2002, Boyko and McLaughlin, 2010) and H. strigillata (Stimpson, 1860) (Hendrickx, 1995; Hendrickx and Harvey, 1999). Hippa marmorata occurs from the central Gulf of California to Colombia, including several oceanic islands of the eastern Pacific (Revillagigedo, del Coco, Galapagos, and Clipperton) (Hendrickx, 2005). Hippa strigillata was described from specimens collected in Cabo San Lucas, and additional material has been reported since by only a few authors. Efford (1972) described the distribution of the species in the eastern Pacific and reported material from Los Frailes, on the west coast of the Baja California Peninsula, from several localities in western Mexico, and from El Salvador. Ramos and Ríos (1995) collected material in Ensenada de Utría, Colombia, providing a new southernmost record and new size record for the species. Subsequent citations did not report on new material and referred exclusively to previously cited localities. The northernmost distribution limit is currently in Mazatlán, on the east side of the Gulf of California, and in Los 
Frailes, on the west coast. The collections data corresponding to Mazatlán, however, were never published. This contribution presents details of these collections and new, recent records of $H$. strigillata in the area of the Bay of Mazatlán, Mexico.

Samples of $H$. strigillata were collected by hand in the Bahía de Mazatlán and surounding area, along the Pacific coast of Mexico (see Material examined), in the surf zone with a push net (samples of 1982) or in the intertidal with a shovel and a sieve (samples of 2012) of $1.8 \mathrm{~mm}$ aperture. Sampling localities were obtained from Google Map (January 2014) and plotted on a map of the area. Carapace width $(\mathrm{CW})$ and length (CL) were measured with a Vernier (precision $\pm 0.01 \mathrm{~mm}$ ). All the specimens are kept in the Regional Collection of Marine Invertebrates, at the Instituto de Ciencias del Mar y Limnología, UNAM, Mazatlán, Mexico (EMU).

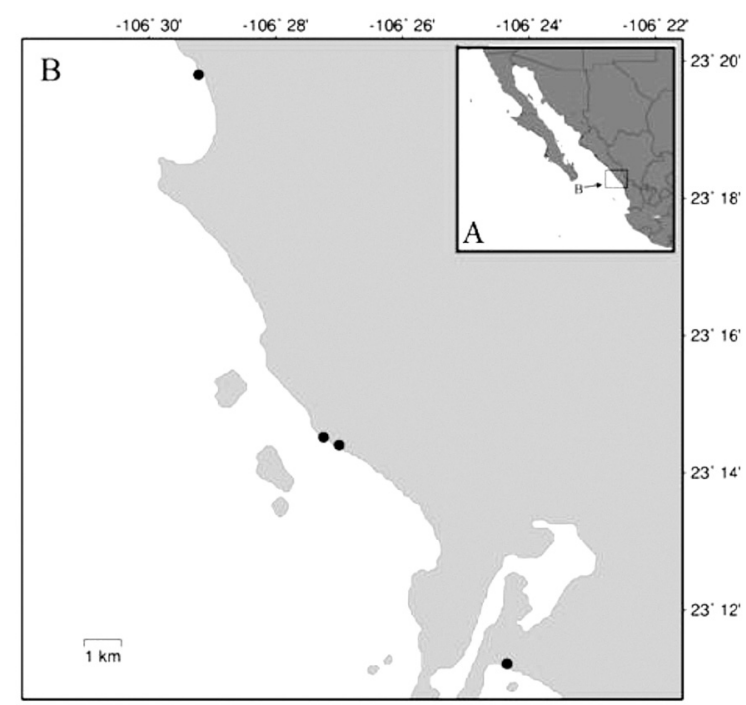

Figure 1. Distribution of Hippa strigillata (Stimpson, 1860) in the area of the Bay of Mazatlán, southeastern Gulf of California, Mexico (Map adapted from seaturtle.org/maptool. Mercator projection; January 2014).

\section{Hippa strigillata (Stimpson, 1860)}

Remipes strigillatus Stimpson, 1860: 113. Hippa strigillata. - Efford, 1972: 121; Haig, 1980: 289, textfig. 19.4; Hendrickx, 1993a: 308 (list); 1993b: 7 (list); 1995: 564; 1996: 614 (appendix 1); 2005: 178 (list); Ramos and Ríos, 1995: 102; Hendrickx and Harvey, 1999: 367 (list); Boyko and McLaughlin, 2010: 142 (list).
Materialexamined:Playa el Delfín (2319'48”N / 106029'13"W), north of Mazatlán, 13/ Oct/1982, 8 males (CW, 7.07-11.81 mm; CL, 8.28-14.20 mm), push net, surf zone (EMU-1228); Punta Sábalo (2314’24”N / 106²7’W), Mazatlán, 5/Oct/1982, 1 male (CW, $7.15 \mathrm{~mm}$; CL, $8.60 \mathrm{~mm}$ ), push net, surf zone (EMU-2788); Playa Las Flores (231' $31^{\prime \prime N ~ / ~ 106 ² 7 ' 15 ” W), ~ M a z a t l a ́ n, ~ 2 / ~}$ Feb/2012, 3 males (CW, 5.42-6.83 mm; CL, 7.11-8.96 mm) and 2 females (CW, 5.53-6.43 $\mathrm{mm}$; CL, 7.63-8.34 mm), sieve, surf zone (EMU-9882A). Same locality, 2/Mar/2012, 8 males (CW, 5.45-8.22 mm; CL, 7.07$10.21 \mathrm{~mm}$ ) and 4 females (CW, 4.89-7.85 $\mathrm{mm}$; CL, 6.49-10.19 mm), sieve, surf zone (EMU-9881A). Same locality, 8/May/2012, 1 male (CW, $5.30 \mathrm{~mm}$; CL, $6.97 \mathrm{~mm}$ ), and 1 female (CW, 7.91 mm; CL, $10.09 \mathrm{~mm}$ ), sieve, surf zone (EMU-9881B and 9882B); Isla de la Piedra $\left(23^{\circ} 11^{\prime} 13^{\prime \prime N} / 1^{\circ} 24^{\prime} 21^{\prime \prime W}\right)$, Mazatlán, 3/Feb/2012, 1 female (CW, 6.59 $\mathrm{mm}$; CL, $8.32 \mathrm{~mm}$ ), sieve, surf zone (EMU9882C).

Type locality: San Lucas Cape, Baja California, Mexico (Efford, 1972).

Maximum known size: Up to $25 \mathrm{~mm}$ (CL) (Haig, 1980).

Distribution: Mexico: Los Frailes and Cabo San Lucas, southern Baja California; Mazatlán, Sinaloa; Puerto Vallarta, Jalisco; Bahía de Petalco, Zihuatanejo, and Acapulco, Guerrero; La Libertad, El Salvador (Efford, 1972); Ensenada de Utría, Colombia (Ramos and Ríos, 1995).

Remarks: The maximum known size was recorded by Haig (1980: 25 mm CL). Ramos and Ríos (1995) reported maximum sizes (CL) of $10.1 \mathrm{~mm}$ for males and $13.7 \mathrm{~mm}$ for ovigerous females. In this study, maximum sizes (CL) were $14.20 \mathrm{~mm}$ for males and 10.19 $\mathrm{mm}$ for females. A total of 29 specimens was collected, of which $27.6 \%$ were females and $72.4 \%$ males ( $\mathrm{H}: \mathrm{M}$ proportion, $0.38: 1$ ).

The specimens collected in 2012 in Bahía de Mazatlán were sampled together with a large series of specimens of Emerita 
rathbunae Schmitt, 1935 in the intertidal, mostly at low tide. Emerita rathbunae, however, was proportionally much more abundant (99.21\% of all collected specimens) than $H$. strigillata (0.79\%). In Colombia, H. strigillata is sympatric with $H$. marmorata (Ramos and Ríos, 1995), while in Bahía de Mazatlán it was found together with E. rathbunae and juveniles of Lepidopa sp.

It is rather surprising that no specimens of $H$. strigillata have been found north of Mazatlán as long, uninterrupted sandy beaches are found all the way up to the northern Gulf of California area. Hippa marmorata, for example, has been observed up to El Sahuaral, Sonora (264ㄷㄴ $\left.57^{\prime \prime N} / 109^{\circ} 45^{\prime} 37^{\prime \prime} \mathrm{W}\right)$. Considering that both species of Hippa seem to share a similar habitat (the surf zone in tropical and subtropical areas) there seems to be no clear reason why they cannot be found together in higher latitudes in the Gulf of California.

ACKNOWLEDGEMENTS - We thank José Salgado $\mathrm{B}$. for his assistance during the sampling in the Bay of Mazatlán.

\section{REFERENCES}

Barnes, N.B. and Wenner, A.M. 1968. Seasonal variation in the sand crab Emerita analoga (Decapoda, Hippidae) in the Santa Barbara area of California. Limnology and Oceanography, 13: 465-475.

Boyko, C.B. 2002. Remipespacificus Dana, 1852 (currently Hippa pacifica; Crustacea, Anomura): proposed precedence over Remipes marmoratus Jacquinot, 1846. Bulletin of Zoological Nomenclature, 59(1): 12-16.

Boyko, C.B. and McLaughlin, P.A. 2010. Annotated checklist of anomuran decapod crustaceans of the world (exclusive of the Kiwaoidea and families Chirostylidae and Galatheidae of the Galatheoidae) Part IV-Hippoidea. The Raffles Bulletin of Zoology, 23: 139-151.

Brusca, R.C. 1980. Common intertidal invertebrates of the Gulf of California. Revised and expanded second edition. The University of Arizona Press. 513 p.

Dexter, D.M. 1976. The sandy-beach fauna of Mexico. The Sourhwestern Naturalist, 20(4): 479-485.

Efford, I.E. 1972. The distribution of the sand crabs, Hippa stragillata (Stimpson) and Hippa pacifica (Dana) in the eastern Pacific Ocean (Decapoda, Anomura). Crustaceana, 23(2): 119-122.

Haig, J. 1980. Arthropoda: Crustacea Superfamily Hippoidea: Families Hippidae and Albuneidae (Mole and Sand Crabs). p. 286-291. In: Brusca, R.C. (ed.), Common Intertidal Invertebrates of the Guf of California. Revised and expanded $2^{\text {nd }}$ Edition. The University of Arizona Press, Tucson, Arizona.
Hendrickx, M.E. 1993a. Crustáceos decápodos del Pacífico Mexicano. p. 271-318. In: S.I. Salazar-Vallejo and N.E. González (eds), Biodiversidad Marina y Costera de México. Comisión Nacional para el Estudio y Uso de la Biodiversidad y CIQRO, México, 865 p.

Hendrickx, M.E. 1993b. Crustáceos decápodos bentónicos del sur de Sinaloa, México. Anales del Instituto de Biología, UNAM, México, 64(1): 1-16.

Hendrickx, M.E. 1995. Anomuros. p. 539-564. In: W. Fischer; F. Krupp; W. Schneider; C. Sommer; K.E. Carpenter and V.H. Niem (eds), Guía FAO para la identificación de especies para los fines de la pesca. Pacífico centro-oriental. Vol. I. Plantas e Invertebrados. 646 p. FAO, Roma, Italia.

Hendrickx, M.E. 1996. Habitats and biodiversity of decapod crustaceans in the SE Gulf of California, Mexico. Revista de Biología Tropical, 44(2A): 603-617.

Hendrickx, M.E. 2005. Cap. 14. Crustacea 6. Decapoda: Dendrobranchiata, Caridea, Palinura, Anomura \& Brachyura. p. 159-194. In: M.E. Hendrickx; R.C. Brusca and L.T. Findley (eds), A Distributional Checklist of the Macrofauna of the Gulf of California, Mexico. Part I. Invertebrates. [Listado y Distribución de la Macrofauna del Golfo de California, México, Parte I. Invertebrados]. Arizona-Sonora Desert Museum. 429 p.

Hendrickx, M.E. and Harvey, A.W. 1999. Checklist of anomuran crabs (Crustacea: Decapoda) from the eastern tropical Pacific. Belgian Journal of Zoology, 129(2): 327-352.

Jaramillo, E.; Duarte, C. and Contreras, H. 2000a. Sandy beach macroinfauna from the coast of Ancud, Isla de Chiloé, Southern Chile. Revista Chilena de Historia Natural, 73(4): 771-786.

Jaramillo, E., Dugan, J. and Contreras, H. 2000 b. Abundance, tidal movement, population structure and burrowing rate of Emerita analoga (Anomura, Hippidae) at a dissipative and a reflective sandy beach in south central Chile. Marine Ecology, 21(2): 113-127.

Ramos, G.E. and Rios, R. 1995. Los 'reculambai' o 'canchunchos' (Crustacea: Decapoda: Hippoidea: Hippidae y Albuneidae) de la costa del Pacífico de Colombia. p. 92-109. In: J.R. Cantera and J.D. Restrepo (eds), Delta del Río San Juan, Bahías de Malaga y Buenaventura, Pacífico Colombiano. Tomo II. Colciencias, Universidad EAFIT y Universidad del Valle.

Ríos-Elósegui, D.G. 2013. Abundancia, relaciones biométricas y fecundidad del cangrejo de arena Emerita rathbunae (Schmitt, 1935) (Decapoda: Anomura: Hippidae) en el área de Mazatlán, Sinaloa. Tésis de Licenciatura. Facultad de Ciencias del Mar, Universidad Autónoma de Sinaloa. 87 p.

Tait, R.V. 1972. Elements of marine ecology: an introductory course. $2^{\text {nd }}$ Edition. 314 p. Butterworth.

Stimpson, W. 1860. Notes on North American Crustacea, in the Museum of the Smithsonian Institution. No II. Annals of the Lyceum of Natural History, New York, 7: 49-118, Plates I-III. 